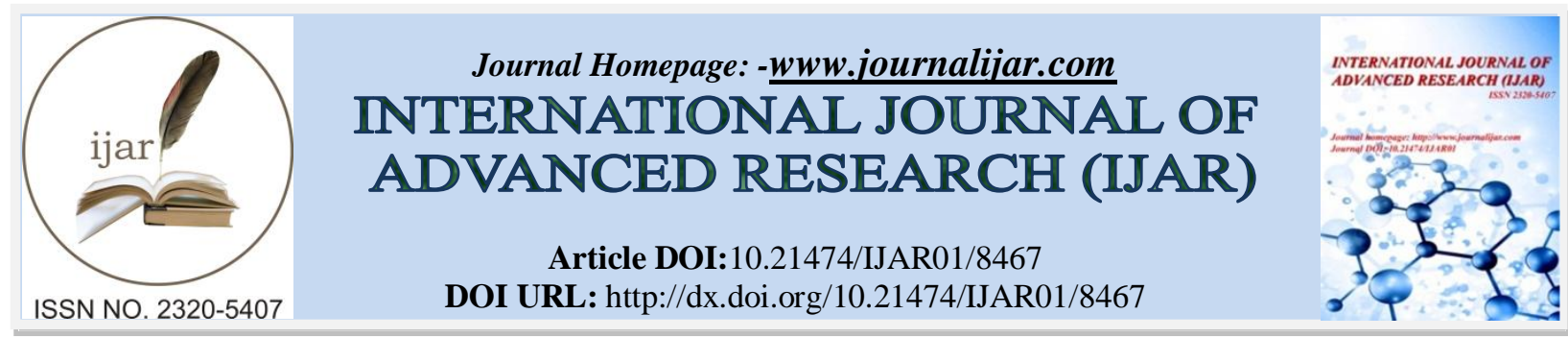

RESEARCH ARTICLE

\title{
A COMPARATIVE STUDY OF ANTIFUNGAL ACTIVITY OF ETHENOLIC LEAF AND SEED EXTRACTS OF ANNONA SQUAMOSA L.
}

\author{
Sanjay Prasad Gupta ${ }^{1}$, Manager Singh ${ }^{1}$, Neeta Nigam $^{1}$, Iliyas Ahmed ${ }^{1}$, Pawan Kumar ${ }^{2}$ and D. N. Sharma ${ }^{3}$ \\ 1. National Research Laboratory for Conservation of Cultural Property, Lucknow, India. \\ 2. Geological Survey of India, Lucknow, India. \\ 3. Kalyan P. G. College, Bhilai, Chhattisgarh, India.
}

\section{Manuscript Info}

\section{Manuscript History}

Received: 02 December 2018

Final Accepted: 04 January 2019

Published: February 2019

Key words:-

Annonasquamosa L., fungicidal activity, extract, phytochemical test, ethanolic seed extract.

\begin{abstract}
A comparative study of antifungal activity of ethanolic extracts of the leaves and seeds of Annonasquamosa L. (A plant of Annonaceae Family, commonly known as custard apple-sitafal) were evaluated against four fungi namely, Rhizopusnigricans, Aspergillusniger, Culvularialunata and Cladosporiumcladosporioides using agar well and disc diffusion method. Maximum inhibition was found with $50 \mathrm{mg} / \mathrm{ml}$ concentration of ethanolic seed extracts against all the tested organisms under investigation. The study suggests that the seeds of A. squamosa are promising source for the development of suitable phytomedicine having fungicidal properties in place of commonly and widely used chemical antifungal agents.
\end{abstract}

Copy Right, IJAR, 2019,. All rights reserved.

\section{Introduction:-}

The populations of human being living in the developing countries mostly rely on traditional medicine for their primary health care needs. Similarly, plant materials are also used to prevent crop from harmful micro-organisms. Thus, the characterisation of the chemical composition and the study of the antimicrobial behaviour of the medicinal plants may provide us the basis for development of herbal drugs and phytomedicinal agents. However among the estimated 2,50,000-4,00,000 plant species, only 6\% have been studied for biological activity and about $15 \%$ have been investigated phytochemically [1,2]. The Therapeutic efficacy of many indigenous plants, for various diseases has been described by traditional herbal medicinal practitioners [3, 4]. There are numerous reasons that people of world using plants for medication. This includes treatment and improvement of health after herbal treatment through medicinal plants, reasonable cost of the drugs, no any side effect, non availability of synthetic drugs particularly in the rural areas and in some cases the people are more accustomed to and comfortable with traditional healing [5]. Annonaceae is one of the biggest families, which comprising about 150 genera over 1500 species are Annona, with about 100 species, genera, the species of Annonasquamosais a small evergreen tree reaching 6-12 feet tall, is commonly found in deciduous forests, cultivated throughout India and other countries. It is commonly called as custrard apple or sarifa or sitafal, it is native of West Indies. Sitafal is tradionally used for the treatment of epilepsy, dysentery, cardiac problem, worm infection, constipation, haemorrhage, antibacterial infection, dysuria, fever, and ulcer. However, A. squamosa seed cotyledon have been found to have antimicrobial and anti-insecticidal properties but the comparative account of antimicrobial and anti insecticidal properties of root, leaf and seed cotyledon are not well reported. In view of the above, in present investigation, a comparative study of fungicidal properties of ethanolic extracts of leaves and seed cotyledons of $A$. squamosaL. is presented.

Corresponding Author:-Sanjay Prasad Gupta.

Address:-National Research Laboratory for Conservation of Cultural Property, Lucknow, India. 


\section{Materials And Methods:- Collection of plant material}

The leaves of A. Squamosa L. were collected from park of Lucknow and seeds were purchased from the market of Lucknow, India and brought to laboratory. The collected leaves and seeds were thoroughly washed with tap water and then rinsed with sterile distilled water. The leaves of plant were shed dried for week whereas seed was dried in oven at $50^{\circ} \mathrm{C}$ for 36 hours before grinding in electric mixer. The powder materials were kept in airtight glass bottles. This stock powder were used for further extraction [6[.

\section{Extraction of plant material by Soxhlet apparatus}

The solvents with varied polarity solubilise plant biomolecules differently due to difference in their polarities. Considering it's polarity,ethanol was preferred to be used as solvent for extraction. Activity of extracted material was determined using agar diffusion method $[6,7]$.

$5.00 \mathrm{gm}$ of each dried and ground leaves and seeds were placed in different whattman cellulose extraction thimble $(43 \mathrm{~mm} \times 123 \mathrm{~mm})$ with single thickness. Samples were extracted in a Soxhlet extraction system using $150 \mathrm{ml}$ of solvent in each case. The heating power was set to two cycles/hour so that six cycles of extraction were achieved within 03 hours (Fig.3). Rotary vacuum evaporator used for evaporation of solvent from crude and completely dried in atmospheric oven at low temperature. High temperature was avoided to minimize the component degradation [6,8]. All extracts were then stored at room temperature. The stock solutions of the extracts were prepared in dimethyl sulfoxide (DMSO). The extracts were further diluted with DMSO to prepare a series of solutions containing 10,20,30,40 and $50 \mathrm{mg} / \mathrm{ml}$ concentrations for the investigation of inhibition of growth of fungal species. The fungal species were taken in petriplates and extracts of different dilutions were applied on them. Control treatment was done without using any plant extract in petriplate. The range of activity of extract was determined by dilution method and activity was calculated by slandered formula that we have incorporated in material and method part. Percentage inhibition of fungi growth by the leaf extracts was calculated using formula $[6,9]$.

$\mathrm{FG}=\{(\mathrm{Dc}-\mathrm{Dr}) / \mathrm{Dc}\} \times 100$

FGI $=100-\mathrm{FG}$

Where-

$\mathrm{FG}=$ fungal growth in \%

$\mathrm{Dc}=$ Diameter of control $(\mathrm{mm})$

Dr=Diameter of test (mm)

FGI= Fungal Growth Inhibition in \%

\section{Agar-well diffusion method}

A loopfull of the inoculums suspension of two sets of pure 04 cultured identified fungal organism were spread uniformly on the solidified sterile culture media (PDA) in the Petri plates for uniform distribution of the organism. Using a sterile cork borer a well of $0.5 \mathrm{~cm}$ was made in the media and in each well, plant extracts were filled to allow the diffusion of plant extracts in the media. The Petri plates were incubated at for 24 hours at $30^{\circ} \mathrm{C}$ temperature and the observations were recorded as diameter of inhibitory zone in $\mathrm{mm}$. Well in agar plate filled with sterile distilled water was used as control in all the experiments [6,10]. All experiments were performed in triplicates and the mean inhibition percentages are presented in the observation table.

\section{Disc diffusion method}

Disc diffusion method was followed by taking sodium pentachlorophenate as standard antibiotic for fungi. High potency bio-discs (Himedia) were prepared and placed on the lawn spreaded agar. After 2 days incubation at $26^{\circ} \mathrm{C}$ for all 04 identified fungi viz.Rhizopusnigricans, Aspergillusniger, Culvularialunata and Cladosporiumcladosporioides the plates were examined and the minimum inhibitory concentrations were measured.

\section{Results And Discussion:-}

In the present investigation, four fungal cultures were tested to determine the antifungal activity of ethanolic extract of A. Squamosa leaves and seeds. The FGI values given in tables -1 are the mean of the three observations. The ethenolic leaf extract revealed maximum inhibition at $50 \mathrm{mg} / \mathrm{ml}$ in Culvularialunata $(11 \mathrm{~mm})$ followed by Rhizopusnigricans, $(9 \mathrm{~mm})$, Cladosporiumcladosporioides $(8 \mathrm{~mm})$ and A.niger $(7 \mathrm{~mm})$. Maximum inhibition for seed 
extracts was observed at $50 \mathrm{mg} / \mathrm{ml}$ concentration in Culvularialunata $(11 \mathrm{~mm})$, followed by A.niger $(9 \mathrm{~mm})$ and Cladosporiumcladosporioides $(9 \mathrm{~mm})$ but no effect was observed on Rhizopusnigricans. The standard sodium pentachlorophenate at $100 \mu \mathrm{g} / \mathrm{ml}$ showed highest inhibition in Cladosporiumcladosporioides $(17 \mathrm{~mm})$, followed by Aspergillusniger $(15 \mathrm{~mm})$, Rhizopusnigricans $(13 \mathrm{~mm})$, and Culvularialunata $(13 \mathrm{~mm})$. Among the plant materials, the seed extracts showed better inhibition as compared to leaf extract (Table-1).

This study shows that ethanol seed extracts inhibited the growth of Aspergillusniger, Culvularialunata and Cladosporiumcladosporioideseffectively and no antifungal effect was observed on Rhizopusnigricans. Other such studies also support this finding [11]. The leaf extracts were active against all the tested fungi. There were marked differences between the antifungal activities of the plant leaf $\&$ seed extracts and those of the pure antifungal drugs (Sodium pentachlorophenate). Such significant differences normally present when crude (unpurified) plant extracts are compared with pure drug that are already in clinical use [12]. The plant extracts having potential antifungal activities preferably be used for prevention and conservation of cultural properties as chemical agents normally used for such work are not eco-friendly. In this investigation, the inhibition values are almost similar and highest at $50 \mathrm{mg} / \mathrm{ml}$ concentration of both ethanol leaf and seed extracts for Culvularialunata and is comparable to the effect of sodium pentachlorophenate solution on the same species. These results are almost similar to the observations of other researchers [13].

Table 1:-Antifungal activity of ethanolic crude extracts of Annonasquamosaleaves and seed cotyledons.

\begin{tabular}{|c|c|c|c|c|c|}
\hline \multirow[t]{2}{*}{ Samples } & \multirow{2}{*}{$\begin{array}{l}\text { Conc. } \\
\text { of } \\
\text { Extract } \\
(\mathrm{mg} / \mathrm{ml} \mathrm{l}\end{array}$} & \multicolumn{4}{|c|}{ Fungal Growth Inhibition ( } \\
\hline & & $\begin{array}{l}\text { Rhizopusnigrica } \\
\text { ns }\end{array}$ & $\begin{array}{l}\text { Aspergillusnig } \\
\text { er }\end{array}$ & $\begin{array}{l}\text { Culvularialunat } \\
\text { a }\end{array}$ & $\begin{array}{l}\text { Cladosporiumcladosporioid } \\
\text { es }\end{array}$ \\
\hline \multirow[t]{5}{*}{ Leaf Extract } & 10 & 0 & 0 & 0 & 3 \\
\hline & 20 & 7 & 6 & 7 & 5 \\
\hline & 30 & 9 & 5 & 8 & 7 \\
\hline & 40 & 8 & 6 & 8 & 8 \\
\hline & 50 & 9 & 7 & 11 & 8 \\
\hline \multirow[t]{5}{*}{ Seed Extract } & 10 & 0 & 0 & 6 & 0 \\
\hline & 20 & 0 & 6 & 9 & 5 \\
\hline & 30 & 0 & 7 & 12 & 7 \\
\hline & 40 & 0 & 9 & 12 & 9 \\
\hline & 50 & 0 & 9 & 12 & 9 \\
\hline Control & 0 & 0 & 0 & 0 & 0 \\
\hline $\begin{array}{l}\text { Sodium } \\
\text { pentachlorophena } \\
\text { te }\end{array}$ & $\begin{array}{c}100 \\
\mu \mathrm{g} / \mathrm{ml}\end{array}$ & 13 & 15 & 13 & 17 \\
\hline
\end{tabular}

\section{Conclusion:-}

In the present study, the extracts of AsquamosaL leaves and seed cotyledons are found to have wide range of antifungal activity, which confirms such earlier reports. The extracts of A. squamosa seed cotyledons have relatively better antifungal property. The observations reported in this paper may be useful for developing suitable phytomedicinal agents for preventive conservation, especially for cultural properties, paper and allied materials etc. 


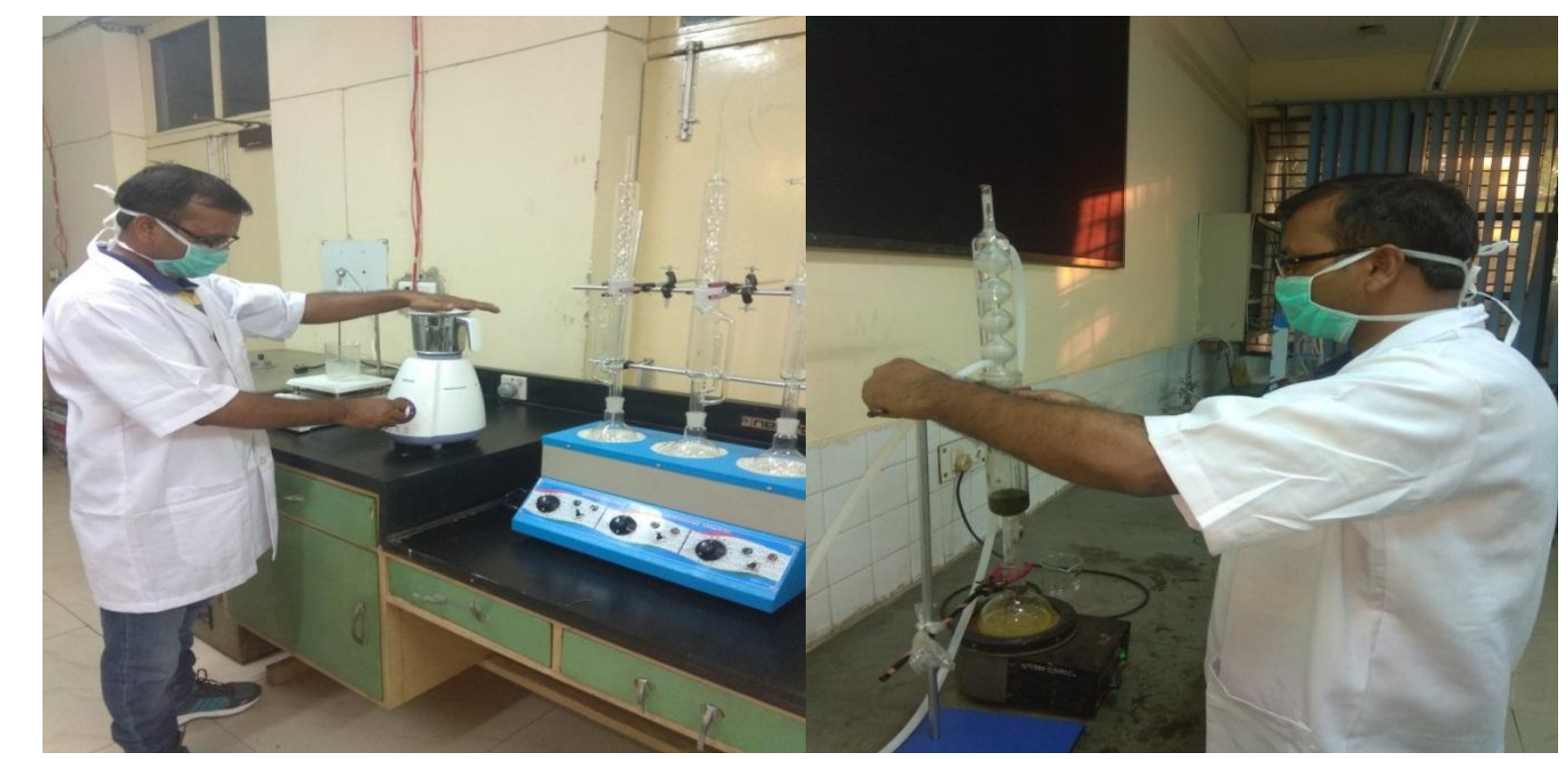

a.

b.

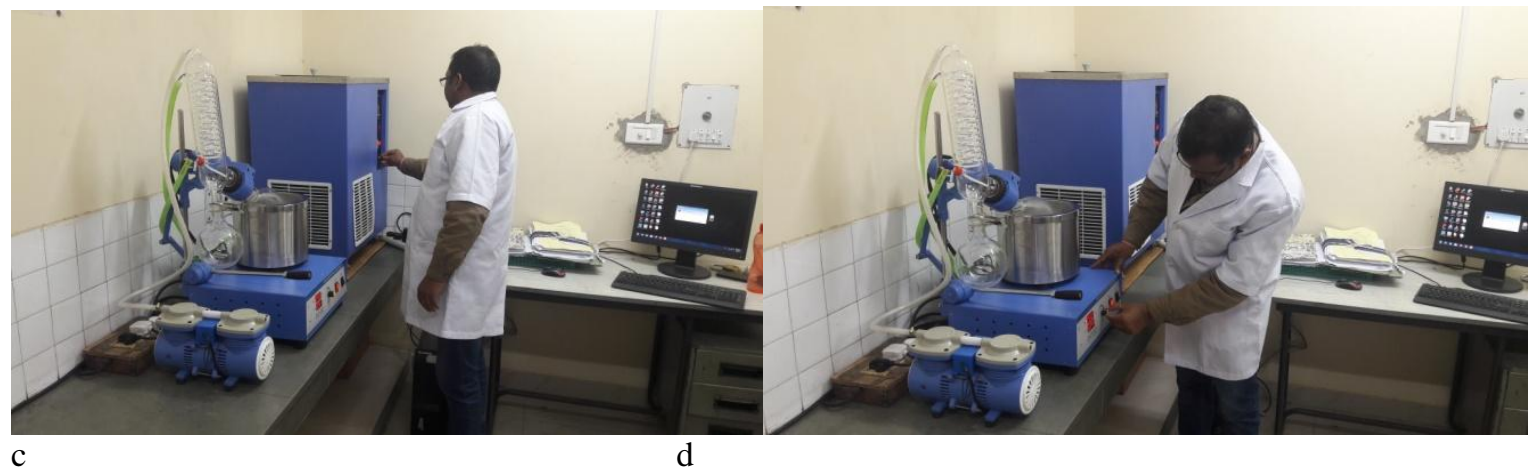

Fig 3:-a-d Extraction of leaf and seed.

Fig 1:-Antifungal activity of ethenolic crude extracts of Annonasquamosa leaves.

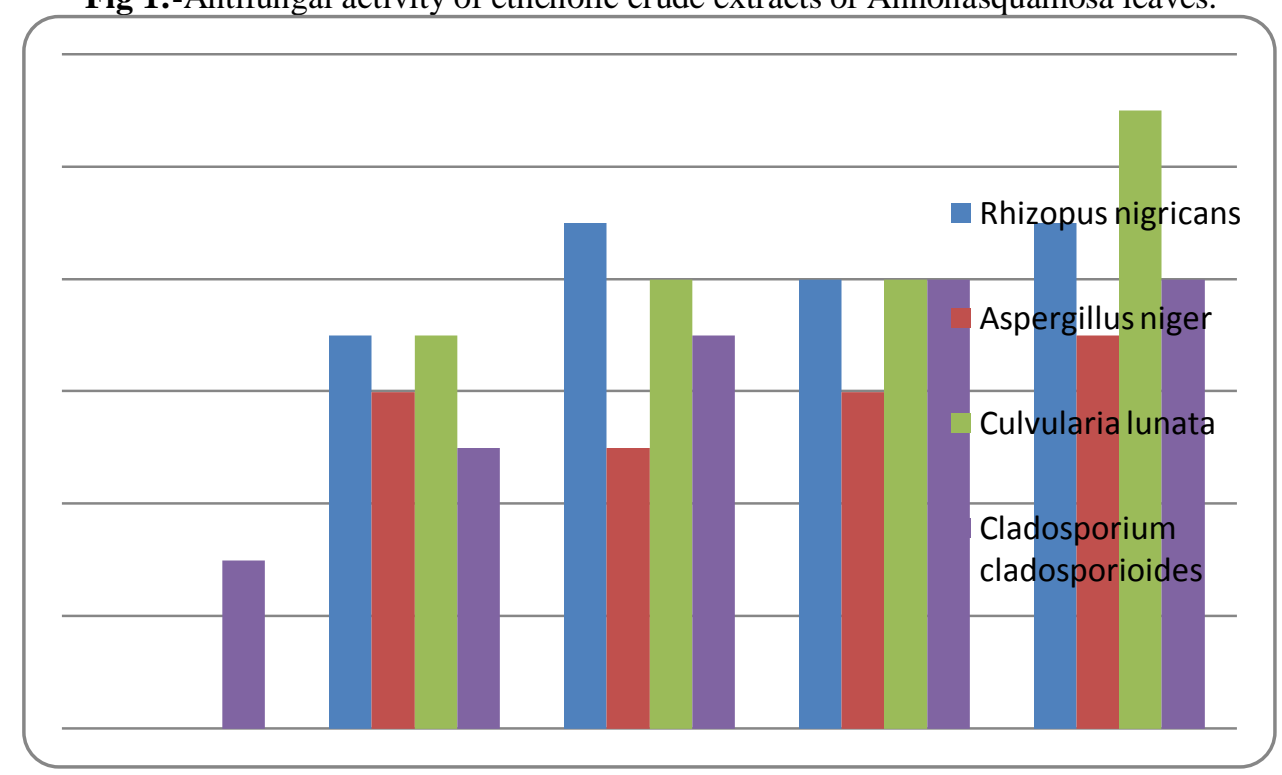


Fig 2:-Antifungal activity of ethenolic crude extracts of Annonasquamosa seed cotyledons.

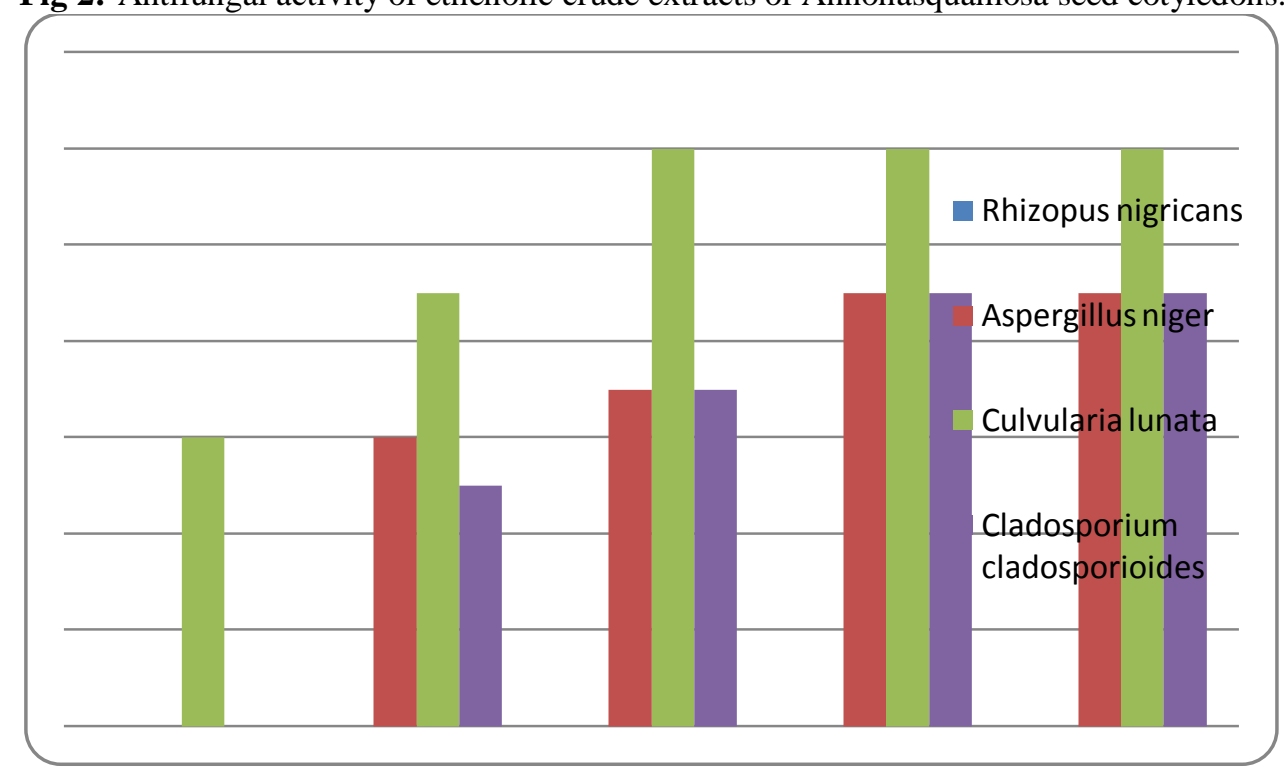

\section{References:-}

1. Balsndrin MF, Klocke JA, Wretele ES, and BoilingerWH.Content and purity of extract solasodine in some available species of solanum. Sciences and culture. 1985; 56 (5): 214-216.

2. Cragg GM, Newman DJ, and Sander KM. Natural products in drug discovery and Development. J. Nat. Prod. 1997; 60: 52-60.

3. GamiB, and Parabia MH. Pharmacognostic Evaluation of Bark and Seeds of Mimusopselengi. Internationa. J of Pharm and Pharmceuti Sci. 2010; 2(4):110-113.

4. Soni H, Sharma S, and Patel SS, etal. Prliminaryphyrochemical Screening and HPLC analysis of Flavonoid from methanolic extract of leaves of AnnonaSquamosa. International research J of Pharm .2011; 2(5):242-246.

5. Audu JA. Studies on the effective of medicinal Herbs Used AsAntihelminitic by traditional medical Practitioners in South of Bauchi State Two. Journal of EconamicTaxanomic Botany. 1995; 19: 653-661.

6. Gupta SP. Eco-friendly approach for conservation of cultural heritage. Aayu Publications, New Delhi. 2016;4548.

7. Onkar D., Dhingra and James. Basic plant pathology method.1995;287-305.

8. Kumaro, AndriCahyo, MasitahHasana and HarcharanSingha. Effects of solvent properties on the soxlate extraction of diterpenoid lactones from Andrographispaniculata leaves. Hort Report. Doi: 10.2306/scienceasia. 2009;1513-1874. Science Asia. 35:306-309.

9. Mondall, NK.,Mojumdar, A., Chatterji A., Banerjee JK. and Gupta S. Antifungal activity and chemical characterisation of neem leaf extracts on the growth of some selected fungal species in vitro culture medium. J.appl.Sci. Environ. Manage. 2009;13(1):49-53.

10. Shinde V. and Dhale DA. Antifungal properties of extracts of Occimum temnuiflorum and Dhaturastramonium against some vegetable pathogenic fungi.J ournal of Phytology. 2011;3(12)41-44.

11. Shyam Prasad G etal. Antibacterial and Antifungal activity of Methanolic extracts of Argemonemexicna Leave, Internationl Journal of Phytopharmacology 2010; 1(2): 64-67.

12. Dickert H, Marchke K, and Bnrveny I. The uses and limitations of Disk diffusion in antibiotic sensitivity testing of Bacteria 1981; 9: 18-24.

13. Srilakshmi D, etal. Antihelmentic activity of Annonasquamosa seed extract. International Journal of Pharmacy \& Technology 2008; 3:1623-1628. 